\title{
36. ACOUSTIC PROPERTIES OF CALCAREOUS CLAYSTONES AND CLAY-RICH CHALKS, DEEP SEA DRILLING PROJECT, LEG 79¹
}

\author{
C. H. Schaftenaar and R. L. Carlson, Texas A\&M University ${ }^{2}$
}

\section{INTRODUCTION}

Laboratory measurements of the acoustic and physical properties of deep-sea sediments and rocks are important for the interpretation of seismic reflection and refraction data and estimation of in situ physical property values. Furthermore, the results of such measurements can be used to design geoacoustic models of the upper oceanic crust that can relate the physical properties of deep-sea sediments to lithology, depth of burial, and diagenetic effects (Hamilton, 1980; Milholland et al., 1980). The purpose of this paper is to report the results of laboratory measurements of wet-bulk density, compressionalwave velocity, and velocity anisotropy on sediments cored during DSDP Leg 79. The sample suite consists of 11 calcareous claystones and clay-rich chalks recovered between 370 to $720 \mathrm{~m}$ sub-bottom at Holes 545 and 547A.

\section{METHODS}

The samples were cut from the split core immediately adjacent to shipboard physical properties samples and carefully packaged in seawater in order to maintain water saturation during shipment to the shore laboratory. Acoustic velocity measurements were made on $2.00 \pm 0.01$ $\mathrm{cm}$ cubes in the vertical (propagation perpendicular to bedding) and horizontal directions at hydrostatic confining pressures up to $0.3 \mathrm{kbar}$. The velocities, determined by the pulse transmission technique using $1 \mathrm{MHz}$ PZT- 5 transducers, are accurate to $\pm 1 \%$. Wet-bulk densities were calculated from the weights and dimensions of the cubes and are accurate to $\pm 1 \%$. Water contents were determined by oven drying the samples at $110^{\circ} \mathrm{C}$ for $24 \mathrm{hrs}$. and reweighing the oven-dried samples. Porosities calculated from the wet-bulk densities and water contents are accurate to approximately \pm 0.02 fractional porosity units. The reported water contents and porosities have not been corrected for salt content of the pore fluid, but approximate corrections can be made by assuming a pore-water salinity of $35 \%$. Corrected values are obtained by dividing the water contents by 0.965 and multiplying the porosities by 1.011 (Boyce, 1976a).

\section{RESULTS AND DISCUSSION}

The physical properties data for the calcareous claystones and clay-rich chalks are summarized in Table 1. Carbonate contents range from 34 to $61 \%$. The densities, water contents, and calculated porosities range from 1.90 to $2.22 \mathrm{~g} / \mathrm{cm}^{3}, 14.1$ to $27.5 \%$, and 30.9 to $52.2 \%$, respectively. Shipboard density and water content measurements made on samples immediately adjacent to the

\footnotetext{
${ }^{1}$ Hinz, K., Winterer, E. L. et al., Init. Repts. DSDP, 79: Washington (U.S. Govt. Printing Office)

2 Address: (Schaftenaar, present address) Chevron, U.S.A., 700 S. Colorado Blvd., Denver, Co. 80222; (Carlson) Department of Geophysics, Texas A\&M University, College Station, TX 77843.
}

samples used in this study are also reported in Table 1 . Because care was taken to select a homogeneous interval for collecting adjacent shipboard and shore lab samples, the physical properties of the subsamples should be similar. However, shipboard measurements yielded consistently higher densities and lower water contents than the corresponding shore values. This suggests that a significant amount of sample expansion, probably because of unloading and the swelling of clay minerals, occurred during the several month interval between the shipboard and shore-based measurements. Presumably, the higher water contents measured at the shore lab indicate that the packaging seawater was absorbed as the samples expanded, however it is not certain that the samples remained fully water saturated during expansion. These density and water content changes illustrate that in order to obtain representative in situ physical property estimates, measurements must be made as soon as possible after core recovery. The problem of expansion is likely to be most serious in claystones and clayrich sediments such as the samples used in this study. However, expansion due to unloading probably occurs in most semilithified sediments.

The compression-wave velocities measured horizontally and vertically at a hydrostatic confining pressure of $0.1 \mathrm{kbar}$ are listed in Table 1 . The degree of water saturation is known to be an important factor affecting the acoustic velocity in rocks (Wyllie et al., 1958). As discussed above, it is not known whether the expansion of the samples affected the water saturation. Nevertheless, the measured velocity values are reasonable for fully water saturated samples, and it is therefore assumed that the samples were completely water saturated at the time of measurement.

Previous studies have shown that deep-sea sediments usually exhibit velocity anisotropy, with compressionalwave velocities higher for propagation in the bedding plane direction than for propagation normal to bedding (e.g., Boyce, 1976b; Bachman, 1979; Carlson and Christensen, 1979; Milholland et al., 1980; Carlson et al., 1983). The anisotropies calculated for this study's suite of calcareous claystones and clay-rich chalks are in good agreement with the previous results. The anisotropies of the 11 samples have a mean of approximately $5.2 \%$ and range from 2.6 to $7.3 \%$.

Several possible causes of velocity anisotropy in deepsea sediments and rocks have been suggested, including preferred orientation of cracks and pores, preferred orientation of mineral grains (Carlson and Christensen, 
Table 1. Summary of physical properties.

\begin{tabular}{|c|c|c|c|c|c|c|c|c|c|c|c|}
\hline \multirow{2}{*}{$\begin{array}{c}\text { Sample } \\
\text { (interval in cm) }\end{array}$} & \multirow{2}{*}{$\begin{array}{l}\text { Depth } \\
\text { (m) }\end{array}$} & \multirow{2}{*}{$\begin{array}{l}\text { Density } \\
\text { shore }\end{array}$} & \multirow{2}{*}{$\begin{array}{l}\left(\mathrm{g} / \mathrm{cm}^{3}\right) \\
\text { ship }\end{array}$} & \multicolumn{2}{|c|}{$\begin{array}{c}\text { Water content } \\
(\%)\end{array}$} & \multirow{2}{*}{$\begin{array}{c}\text { Fractional } \\
\text { porosity }\end{array}$} & \multicolumn{3}{|c|}{$\begin{array}{c}\mathrm{V}_{\mathrm{p}} \text { at } 0.1 \mathrm{kbar} \\
(\mathrm{km} / \mathrm{s})\end{array}$} & \multirow{2}{*}{$\begin{array}{c}\text { Anisotropy } \\
(\%)\end{array}$} & \multirow{2}{*}{$\begin{array}{c}\text { Carbonat } \\
\text { content } \\
(\%)\end{array}$} \\
\hline & & & & shore & ship & & $\mathrm{v}_{\mathrm{h} 1}$ & $\mathrm{~V}_{\mathrm{h} 2}$ & $\mathrm{v}_{\mathrm{v}}$ & & \\
\hline \multicolumn{12}{|l|}{ Hole 545} \\
\hline $40-2,96-98$ & 372.0 & 1.90 & 1.97 & 27.5 & 21.4 & 0.52 & 1.86 & & 1.78 & 4.4 & 34 \\
\hline $42-3,28-31$ & 391.0 & 2.00 & 2.04 & 20.1 & 18.0 & 0.40 & 2.17 & 2.20 & 2.05 & 6.3 & 35 \\
\hline $44-1,56-58$ & 408.1 & 2.08 & 2.14 & 18.4 & 15.6 & 0.38 & 2.20 & & 2.08 & 5.6 & 46 \\
\hline $46-2,73-75$ & 428.8 & 2.12 & 2.16 & 17.7 & 15.2 & 0.38 & 2.24 & & 2.15 & 4.1 & 48 \\
\hline $48-2,41-44$ & 447.4 & 2.10 & 2.16 & 17.9 & 15.1 & 0.38 & 2.22 & 2.20 & 2.09 & 5.5 & 44 \\
\hline $51-3,28-30$ & 477.3 & 2.11 & 2.17 & 17.3 & 14.4 & 0.37 & 2.24 & & 2.13 & 5.0 & 49 \\
\hline $52-2,87-89$ & 485.9 & 2.15 & 2.20 & 15.2 & 13.1 & 0.33 & 2.51 & 2.45 & 2.32 & 6.6 & 47 \\
\hline $54-2,30-32$ & 504.3 & 2.11 & 2.17 & 17.9 & 14.8 & 0.38 & 2.11 & 2.18 & 2.09 & 2.6 & 46 \\
\hline $55-2,91-93$ & 514.4 & 2.21 & 2.26 & 14.0 & 11.6 & 0.31 & 2.41 & & 2.28 & 5.5 & 61 \\
\hline \multicolumn{12}{|l|}{ Hole 547A } \\
\hline $69-2,123-125$ & 709.2 & 2.22 & 2.28 & 14.1 & 11.7 & 0.31 & 2.34 & 2.38 & 2.27 & 3.9 & 60 \\
\hline $70-2,31-33$ & 717.8 & 2.15 & 2.21 & 16.6 & 14.0 & 0.36 & 2.27 & 2.25 & 2.10 & 7.3 & 57 \\
\hline
\end{tabular}

1979; Milholland et al., 1980), and compositional layering (Carlson et al., 1983). Carlson et al. (1983) studied these possible causes in a suite of 40 calcareous deep-sea sediments and concluded that compositional layering (bedding) is the principal cause of velocity anisotropy. However, the contribution of the preferred orientation of clay minerals to the total anisotropy of bedded samples has not been adequately evaluated. The anisotropies measured in the samples investigated in this study are probably primarily due to bedding, but because of the large clay mineral component of these rocks, a significant contribution to the total anisotropy is possible from the preferred orientation of clay minerals.

\section{ACKNOWLEDGMENTS}

We wish to thank N. I. Christensen for the use of his high pressure laboratory. This research was supported by Office of Naval Research Contract N-00014-80-C-0013.

\section{REFERENCES}

Bachman, R. T., 1979. Acoustic anisotropy in marine sediments and sedimentary rocks. J. Geophys. Res., 84:7661-7663.

Boyce, R. E., 1976a. Definitions and laboratory techniques of compressional sound velocity parameters and wet-water content, wet- bulk density, and porosity parameters by gravimetric and gamma ray attenuation techniques. In Schlanger, S. O., Jackson, E. D., et al., Init. Repts. DSDP, 33: Washington (U.S. Govt. Printing Office), 931-957.

1976b. Sound velocity-density parameters of sediments and rocks from DSDP Drill Sites $315-318$ on the Line Islands Chain, Manihiki Plateau, and Tuamotu Ridge in the Pacific Ocean. In Schlanger, S. O., Jackson, E. D., et al., Init. Repts. DSDP, 33: Washington (U.S. Govt. Printing Office), 695-728.

Carlson, R. L., and Christensen, N. I., 1979. Velocity anisotropy in semi-indurated calcareous deep-sea sediments. J. Geophys. Res., $84: 205-211$.

Carlson, R. L., Schaftenaar, C. H., and Moore, R. P., 1983. Causes of compressional-wave anisotropy in calcareous sediments from the Rio Grande Rise. In Barker, P. F., Carlson, R. L., Johnson, D. A., et al., Init. Repts. DSDP, 72: Washington (U.S. Govt. Printing Office), 565-576.

Hamilton, E. L., 1980. Geoacoustic modeling of the sea floor. J. Acoust. Soc. Am., 68:1313-1340.

Milholland, P., Manghnani, M. H., Schlanger, S. O., and Sutton, G. H., 1980. Geoacoustic modeling of deep-sea carbonate sediments. J. Acoust. Soc. Am., 68:1351-1360.

Wyllie, M. R. J., Gregory, A. R., and Gardner, G. H. F., 1958. An experimental investigation of factors affecting elastic wave velocities in porous media. Geophysics, 23:459-493.

Date of Initial Receipt: May 31, 1983

Date of Acceptance: October 25, 1983 